\title{
Corporate Sustainability Reporting and Measuring Corporate Performance
}

\author{
Zuzana Chvatalová, Alena Kocmanová, and Marie Dočekalová \\ Brno University of Technology, Faculty of Business and Management, \\ Kolejni 4, 61200 Brno, Czech Republic \\ \{chvatalova, kocmanova, docekalova\} afbm.vutbr.cz
}

\begin{abstract}
Corporate sustainability reporting and the measurement of environmental, social, economic and governance performance are discussed in the paper. These are necessary tools of top management for the company strategy choice of sustainable success. In doing so, the relationship between company performance and these factors is important, therefore, the need to develop the modern and advanced methods and metrics to identify them mainly based on the quantification with the possibility of utilization of information and communication technology. This is discussed in the paper.
\end{abstract}

Keywords: Corporate Sustainability Reporting; Corporate Performance; GRI; KPI; Modelling.

\section{Introduction}

As regards the environmental, economic, social and corporate governance aspects in relation to measurement of company performance, also the Corporate Sustainability Reporting is gaining importance. Corporate Sustainability Reporting has become a mainstream business activity. The Amsterdam Declaration on Transparency and Reporting of the Board of the Global Reporting Initiative (GRI) ${ }^{1}$ from March 2009 told to global leaders from business, labour and civil society declared their belief that the lack of transparency in the existing system for corporate reporting has failed its stakeholders. It brought a new impulse to reporting on environmental, social and governance (ESG) performance.

The development in the field of corporate sustainability and environmental reporting in the Czech Republic reflect the overall global world trends; see [4]. The available statistics show that through all objective benefits the corporate sustainability reporting can bring to businesses an appropriate feedback. Existing motivation is not sufficient to make this a normal business practice as compared to the financial accounting and reporting. On the one hand, some large corporations are actively performing GRI; on the other hand, the relative share of these companies is rather small. Plenty of companies in the Czech Republic have implemented and certified an Environmental Management System (EMS) as a part of integrated management system (quality, environment and occupational health and safety management). Therefore,

${ }^{1}$ http://www.globalreporting.org/aboutgri/whatisgri/history/amsterdamdeclaration 
the environmental, economical and social data and information are being monitored, codified, registered and aggregated into Key Performance Indicators (KPIs) ${ }^{2}$. This fact indirectly indicates that in the case of such need the company is able to aggregate these data and incorporate it into the corporate sustainability or environmental report, see [4].

Although the GRI has served as an essential and very useful means in improving the standardisation of company reporting, companies continue to have differing degrees of compliance with the GRI and sometimes differing interpretations of the best means to apply the standards to their reporting. To be comparable across all companies, and thus useful for mainstream investment analyses, it is important that economic, environmental, social and governance data is transformed into consistent units and is presented in a balanced and coherent manner in ESG indicators.

\section{GRI and UNEP FI Proposals}

There the Board of GRI concluded that the root causes of the current economic crisis would have been moderated by a global transparency and accountability system based on the exercise of due diligence and the public reporting of economic, environmental, social and governance (sustainability) performance. They called on governments to introduce policies requiring companies to address publicly sustainability factors. A revitalized and resilient economic system will only be sustained if it accounts for the full costs and value of sustainability activity. The Board of GRI calls on governments to take leadership by:

- Introducing policy requiring companies to report on sustainability factors or publicly explain why they have not done so;

- Requiring sustainability reporting by their public bodies - in particular: state owned companies, government pension funds and public investment agencies; Integrating sustainability reporting within the emerging global financial regulatory framework being developed by leaders of the G20 (The Group of Twenty) ${ }^{3}$.

Investors have been a key driver in promoting the uptake of sustainability reporting as a result of initiatives such as the United Nations Environment Programme's Finance Initiative (UNEP FI) ${ }^{4}$. They are increasingly asking companies for economic, environmental, social and governance (ESG) information to help them make investment decisions, see [4].

UNEP FI Asset Management Working Group (AMWG) and the Markets \& Valuation Work Stream of the Word Business Council for Sustainable Development have jointly published the new report: "Translating ESG into sustainable business value "S. This report providing key insights for companies and investors on how their business and investment philosophy and practices going forward can better address the why, what and how of communicating corporate economic, environmental, social

\footnotetext{
${ }^{2}$ http://en.wikipedia.org/wiki/Performance_indicator

${ }^{3}$ http://www.g20.org/about_what_is_g20.aspx

${ }^{4} \mathrm{http}: / /$ www.unepfi.org/about/index.html

${ }^{5} \mathrm{http} / / /$ www.unepfi.org/fileadmin/documents/translatingESG.pdf
} 
and governance (ESG) performance to the capital markets. Business leaders and investors can use this report as a tool to advance the integration of ESG factors into corporate and investment decision-making, and to continue discussing the needed evolution towards more holistic and realistic capital market valuation processes.

The AMWG is a global platform of asset managers that collaborate to understand the various ways ESG factors affect investment value and the evolving techniques for the inclusion of ESG criteria and metrics. ${ }^{6}$

From sustainability performance data is necessary to determine KPIs to identify company overall sustainability performance.

Great importance is attributed to the defining of KPIs in the economic, environmental, social and governance areas for a specified economic activities ( $\mathrm{NACE}^{7}$ ) with subsequent measurement of sustainable development. The corporate sustainability reporting and overall performance of a company in a specific economic activity would thus be defined by the integrated achievement of economic, social, environmental and corporate governance performance measures. Sustainability performance is, however, often understood as performance in environmental and social terms, thus excluding economic performance [8].

Decision-making is based on a qualified assessment (measurement) of a situation determined at the same time by multiple factors (indicators), primarily in their horizontal development. In pursuit of an outstanding informative force an emphasis is currently placed not only on the absolute data, but in the first place on the change data and analyses of changes of these changes. That is, dynamics of systems is the focus of attention. Appropriately applied vertical analyses then add further dimension to the conditions for decision making. In this conjunction other methods have to be discussed: logical and empirical methods, methods of qualitative and quantitative research such as in particular modelling of statistics.

\section{Modelling Tools for Measuring Corporate Performance}

"Creating of models of social phenomena is at the heart of economic science. By model we understand here a simplified representation of reality“, see [9]. The process of creating models of real situations (in general, not just in economics) may be called real phenomena modelling. The more real situation aspects the model embraces, the more exactly it describes it. Such a model, however, may not be suitable for understanding context and achieving clearness, processing and further manipulation (obtaining results within a reasonable time span, formulation of conclusions; possible uncovering of strengths and weaknesses of facts or inappropriate use of information technology), see [5], [6]. Modelling may be categorized from different points of view. For example if the focus is on description, this may be of verbal, visual, quantitative, qualitative or analytic kinds. If the focus is on character, this encompasses deterministic and stochastic, static, dynamic and other approaches, see [2].

\footnotetext{
${ }^{6} \mathrm{http}: / /$ www.unepfi.org/work_streams/investment/amwg/index.html

${ }^{7}$ NACE is an acronym standing for Statistical Classification of Economic Activities, used by the European Union (or the European Communities) since 1970. NACE provides a framework for statistical data relating to activities in many economic areas (e.g. production, employment, national accounts).
} 
In connection with the currently ever more demanded change analysis, we have to mention Deming's cycle, i.e. application of what is known as Deming's fourcomponent diagram also referred to as Plan-Do-Check-Act (PDCA) ${ }^{8}$.

When modelling and employing advanced quantitative methods, optimization, stochastic, dynamic, further mathematic (e.g. disaster theories) and other methods in measuring corporate performance, the level of knowledge may be increased by also considering significant aspects of qualitative character, mainly consisting in capturing facts non-deterministically. For example: by capturing phenomena under conditions of indeterminateness; by means of data extraction; by considering and reflecting upon uncertainties not just by "measuring" empirical data; by considering also inaccuracy of methods, technology and the facts that economic, environmental as well as social experiments are difficult to control; by taking into account degrees of phenomenal ambiguity, delimiting certain balance space etc.

The resulting methods for measuring corporate performance should be modifiable, enabling e.g. local specification which takes into account abnormal or marginal conditions, with a potential of reasonable prediction, deduces historical development, single/multi criteria, capable of further simplification (e.g. comparative statics approach) etc.

Graphical possibilities for results of measuring corporate performance such as visualization, animation, simulation etc. are an important support for their understanding. An indispensable tool is presented by the rapidly developing information and communication technologies (ICTs), see [3], [6]. A great number of ICTs exists at present, e.g. the modelling tools Maple, MuPAD, Mathematica, tailor-made for statisticians are the cutting-edge systems Statgraphics, Statistica and others.

Scientific computing thus plays an ever more important role which is even more accentuated by the rapidly developing ICTs, see [5]. In this way new methods are created, but along with that even some older methods have been re-discovered and transferred from their academic environment into practical use.

Mathematicians found inspiration in the nature and developed new theories such as fuzzy logic (determining "how many" elements belong in a specific set), artificial neuron networks (are sort of imperfect model of the human mind, termed "black box", as it is impossible to thoroughly learn about an internal structure of a system), genetic algorithms (used where exact solutions of practical problems would be almost infinitely long if systematically examined) or chaos (describes behaviour of non-linear systems which though having a hidden order, still appear as systems controlled by chance effects). These methods are considered for measuring ESG performance. E.g. by evaluating the development of a time series of collected enterprise data we are using these theories and we may form an idea of a time series future development ESG performance and carry out a qualified decision making process through applying the fuzzy logic rules based on the findings, see [1].

As regards statistical methods inputs into research of ESG performance, the creation of new fuzzy stochastic models is essential at present for the description and evaluation of sets of collected data of ESG factors with dominating indeterminateness. Furthermore, the creation of unconventional mathematic-statistical methods for fitting discrete distributions of probability aimed at categorical analysis of ESG factor

${ }^{8} \mathrm{http} / / /$ en.wikipedia.org/wiki/PDCA 
trends including the testing of statistical hypotheses and multicriterial decisionmaking is crucial. Applied software implementation of these developed methods and their application to real ESG data and information sets is used, see [7].

We also used the conception of managerial functions defined by $\mathrm{H}$. Fayol ${ }^{9}$ to the determination of ESG factors. This is five functions that he named administration/governance functions (planning), organizing, directing, coordinating, controlling. The mentioned functions are interrelated and are characterized as "sequential managerial functions" (sequential functions). Decision-making is one of the parallel managerial functions, permeating the sequential managerial functions [1].

The theory of systems ${ }^{10}$, i.e. system analysis is another important approach for determination of ESG factors based on gradual decomposition of integrated management system of organisation into its subsystems and elements. It focuses on transformation of system inputs into outputs, i.e. behaviour and features of systems.

The construction of methods for rational while at the same sophisticated use of multifactor metric, the creation of change methodology of measuring ESG factors, a methodical handbook for an organisations in specific industry considering modifiability and broad spectral application, will be universally applicable in the commercial, institutional and public spheres.

\section{Corporate Performance}

Corporate sustainability reporting tools designed for the environmental, economic, social and governance corporate performance - Corporate Social Responsibility (CSR), Global Reporting Initiative (GRI) - appear as essential at present. The "Reporting" will thus produce one of the greatest value "products", even if intangible in nature, i.e. information about corporate performance. This, however, needs to be used effectively. The overall corporate performance plays a key role in the general development of a company. The using the reliable method of corporate performance measurement where concurrent acting of multiple ESG factors is in play, can be considered a prerequisite for success not only in decision making, but also with regard to general corporate governance, comparison possibilities, development of healthy competition environment.

\subsection{Economic Performance}

The Economic Performance is based on Financial Reporting. Sources of financial information are: final accounts, annual reports of a company, company financial analysts and managers information, annual reports, stock exchange news, quantified nonfinancial information and statistics, unquantified information.

Sustainability Accounting is an important tool which processes, analyzes and evaluates three pillars of sustainable development in their interaction and context for improving the company performance in fields environmental - economic performance, environmental - social performance and economic - social performance.

\footnotetext{
${ }^{9} \mathrm{http}: / /$ www.hrmguide.co.uk/history/classical_organization_theory_modified.htm

${ }^{10} \mathrm{http}: / /$ statpac.org/walonick/systems-theory.htm
} 
There are often used the economic indicators of targeted for selection strategies (maximizing profits, maximizing total costs, company survival, etc.), using new methods of design and measurement is often reflecting the evolution of economic performance lessons from history and look to the future.

Economic performance indicators can be divided in relation to the surveyed area:

- $\quad$ indicators of liquidity (current ratio, quick ratio, cash ratio, etc.);

- indicators of profitability (ROA - return on assets, ROE - return on equity, ROI - return on investment, ROS - return of sales, etc.);

- $\quad$ indicators of indebtedness (debt ratio, self-financing ratio etc.);

- indicators of financial and asset structure;

- $\quad$ indicators of activity and other, e.g.:

- Benchmarking, EVA (EVA = NOPAT - Capital · WACC, where NOPAT - net operating profit after taxes, Capital - fixed capital in assets, weighted average cost of capital),

- $\quad$ BSC - Balanced Scorecard and other [10].

We use developed ICT tools with above mentioned modelling tools for measuring corporate performance to facilitate the calculations and the visualizations of models of these economic indicators development and these differences.

\subsection{Environmental Performance}

The Environmental Performance (EP) of an organisation is defined as results of an organisation's management of its environmental aspects. In the context of EMS these results can be measured against the organization's environmental policy (i.e. overall intentions and direction of an organization related to its environmental performance as formally expressed by top management); environmental objectives (overall environmental goals, consistent with the environmental policy, that an organization sets itself to achieve); environmental targets (i.e. detailed performance requirements, applicable to the whole organization or parts thereof, that arise from the environmental objectives and that need to be set and met in order to achieve those objectives) and other environmental performance requirements.

We propose environmental KPIs to provide businesses with a tool for the measurement of the environmental performance of organizations [11]. They are quantifiable metrics that reflect the EP of a business in the context of achieving its wider goals and objectives. These environmental KPIs will help businesses to implement strategies by linking various levels of an organisation (business units, departments and individuals) with clearly defined targets and benchmarks of selected economic activities. Environmental KPIs are measures by which the performances of organizations, business units, and their division, departments and employees are periodically assessed.

KPIs are summarized in the Table 1. 
Table 1. Key Performance Indicators [12]

\begin{tabular}{|c|c|c|}
\hline No. & indicator & unit \\
\hline \multicolumn{3}{|c|}{ Efficiency of material consumption } \\
\hline EN1 & annual mass-flow of different materials used & tonnes \\
\hline EN2 & $\begin{array}{l}\text { ratio of the used recycled input materials } \\
\text { expressed in units }\end{array}$ & $\%$ of the total input materials \\
\hline \multicolumn{3}{|c|}{ Energy efficiency } \\
\hline EN3 & total direct energy use & MWh or GJ \\
\hline EN4 & total renewable energy use & $\begin{array}{l}\% \text { of total annual consumption of } \\
\text { energy (electricity and heat) } \\
\text { produced by the organisation from } \\
\text { renewable energy sources }\end{array}$ \\
\hline \multicolumn{3}{|c|}{ Water management } \\
\hline EN8 & total annual water consumption & $\mathrm{m}^{3} /$ year \\
\hline \multicolumn{3}{|c|}{ Waste management } \\
\hline EN22 & total annual generation of waste & tonnes \\
\hline EN22a & total annual generation of hazardous waste & kilograms or tonnes \\
\hline \multicolumn{3}{|c|}{ Biodiversity } \\
\hline EN11a & use of land & $\mathrm{m}^{2}$ of built-up area use of land \\
\hline \multicolumn{3}{|c|}{ Emissions into the air } \\
\hline EN16 & total annual emission of greenhouse gases & tonnes of equivalent $\mathrm{CO} 2$ \\
\hline EN20a & total annual air emission & kilograms or tonnes \\
\hline \multicolumn{3}{|c|}{ Products and services } \\
\hline EN26 & $\begin{array}{l}\text { Initiatives to mitigate environmental impacts } \\
\text { of products and services, and extent of im- } \\
\text { pact mitigation expressed }\end{array}$ & number of initiatives \\
\hline EN27 & $\begin{array}{l}\text { sold products sold and their packaging mate- } \\
\text { rials that are reclaimed by category }\end{array}$ & $\%$ \\
\hline
\end{tabular}

\subsection{Social and Governance Performance}

We have continued in our research from the development of economic and environmental KPIs to "the construction of methods for multifactor measurement of corporate performance in chosen economic (CZ-NACE) activities and the creation of a modifiable and broad-spectrum methodology of their putting into practice."

The main objective of our research is specified by its partial research targets:

1. Analysis of the state-of-art on economic, environmental, social and corporate governance aspects of company performance through targeted research of the world literature and database sources available with using available ICTs tools.

2. Analysis of the current implementation of ESG reporting in chosen economic activities and its justification.

3. Analysis and categorization of contemporary characteristics of the individual pillars: economic, environmental, social and corporate governance (or the attractive sustainability of success) in relation to the measure of progress or dynamics of development of the overall corporate performance.

4. Specification of possibilities for company overall corporate performance measurements in chosen economic activities based on analyses of previous findings. 
Identification of the importance and relative roles of ESG factors with using ESG data and KPIs in the company overall performance.

5. Construction of methods of multifactor measurement of complex company overall performance in chosen economic activities through the advanced quantitative and qualitative methods (in detail mentioned above) while using the ICT tools and defining their practical implementation ability, functionality, modifiability and embracing a broad spectrum of factors.

6. Application of methods for multifactor measurement of company overall performance of chosen economic activities in practice with feedback for possible change correction aimed at further improvement.

The first results of our research were determination of additional KPIs following results [12] in Table 2.

Table 2. Additional KPIs [12]

\begin{tabular}{|c|c|c|}
\hline No. & indicator & unit \\
\hline \multicolumn{3}{|c|}{ Compliance with legislation } \\
\hline EN28 & $\begin{array}{l}\text { Monetary value of significant fines and } \\
\text { total number of non-monetary sanctions for } \\
\text { non-compliance with environmental laws } \\
\text { and regulations }\end{array}$ & thousand of CZK \\
\hline \multicolumn{3}{|c|}{ Economic Benefits of Environmental Conservation Activities } \\
\hline EC1 & $\begin{array}{l}\text { indicating whether activities in } \\
\text { environmental conservation are } \\
\text { economically rational í }\end{array}$ & $\begin{array}{l}\text { Economic benefits / Environmental } \\
\text { conservation costs. }\end{array}$ \\
\hline EC2 & $\begin{array}{l}\text { indicating whether activities in environ- } \\
\text { mental conservation are economically and } \\
\text { social rational }\end{array}$ & $\begin{array}{l}\text { (Economic benefits }+ \text { social cost } \\
\text { reduction) / Environmental conserva- } \\
\text { tion costs }\end{array}$ \\
\hline EC3 & $\begin{array}{l}\text { indicating the efficiency of environmental } \\
\text { improvements made by the pro- } \\
\text { ject/investment activity }\end{array}$ & $\begin{array}{l}\text { Environmental impact reduction / } \\
\text { Environmental conservation costs. }\end{array}$ \\
\hline \multicolumn{3}{|c|}{ Environmental Efficiency of Business Activities } \\
\hline EC4 & $\begin{array}{l}\text { indicating the environmental impact of } \\
\text { business activities and whether those } \\
\text { activities respond to public needs and } \\
\text { expectations is justifiable }\end{array}$ & Sales / Total environmental impact. \\
\hline EC5 & $\begin{array}{l}\text { indicating whether the business activity } \\
\text { generates an appropriate level of profit in } \\
\text { relation to its environmental impact }\end{array}$ & $\begin{array}{l}\text { Value-added business activities / } \\
\text { Total environmental impact. }\end{array}$ \\
\hline
\end{tabular}

\section{Conclusion}

Environmental, social and governance reporting (ESG reporting) tools designed for the corporate ESG performance appear as essential at present. The overall corporate performance plays a key role in its corporate strategic policy and sustainability of success. The creation of reliable methods of corporate performance measurement where concurrent acting of multiple factors is in play can be considered a prerequisite 
for success not only in decision making, but also with regard to corporate governance, comparison possibilities, development of healthy competition environment etc.

The planned and already developed applied software components for measuring corporate performance within our research project Nr. P403/11/2085 have great potential to be used in different application contexts. On the one hand selection and configuration of existing plug-ins leads to new software tools which suit special application contexts due to their dedicated functionality. On the other hand the open source platform is a basis for custom developments of plug-in-based software tools, where the existing source code of modelling tools can be extended or customized. If necessary the GUI elements provided by the open source platform can be used to build a low effort user interface with basic core functionalities. Finally the developed prototype of applied software for measuring corporate performance will be used as a prototype application for the involved SME which can be directly used without further development steps.

Acknowledgments. This paper is supported by The Czech Science Foundation. Name of the Project: Construction of Methods for Multifactor Assessment of Company Complex Performance in Selected Sectors. Reg. Nr. P403/11/2085.

\section{References}

1. Dostál, P., Rais, K., Sojka, Z.: Pokročilé metody manažerského rozhodování. Grada Publishing, Praha (2005)

2. Fábry, J.: Matematické modelování 1. vyd. Praha VŠE v Praze. Nakladatelství Oeconomia, Praha (2007)

3. Gander, W., Hrebicek, J.: Solving Problems in Scientific Computing Using Maple and Matlab, 4th edn. Springer, Heidelberg (2004)

4. Hrebicek, J., Hajek, M., Chvatalova, Z., Ritschelova, I.: Current Trends in Sustainability Reporting in the Czech Republic. In: EnviroInfo 2009. Environmental Informatics and Industrial Environmental Protection: Concepts, Methods and Tools. 23. International Conference on Informatics for Environmental Protection, pp. 233-240. Shaker Verlag, Aachen (2009)

5. Chvatalova, Z.: Company Sustainable Development and Measuring of its Environmental, Social and Governance Factors. In: Management, Economics and Business Development in European Conditions - VII. International Scientific Conference, pp. 40-49. FBM BUT, Brno (2009)

6. Chvatalova, Z.: The Methods of Quantitative Disciplines in the Environment. In: Sustainability Accounting and Reporting on Micro and Macro-Economical Level - Scientific International Conference, Brno, pp. 116-122. University of Pardubice, Pardubice (2010)

7. Karpisek, Z.: Zadeh-Type Fuzzy Probability with Triangular Norms. In: East West Fuzzy Colloquim 2008, HS Zittau, Gorlitz, pp. 126-133 (2008)

8. Schaltegger, S., Wagner, M.: Integrative Management of Sustainability Performance, Measurement and Reporting. International Journal of Accounting, Auditing and Performance Evaluation 3(1), 1-19 (2006)

9. Varian, H.R.: Microeconomic Analysis, 3rd edn. W. W. Norton and Company, New York (1992) 
10. Vecheta, L.: Finanční analýza firmy užitím systému Maple. FBM BUT, Brno. Master’s thesis. Supervisor Zuzana Chvátalová. Brno (2010)

11. Hřebíček, J., Soukopová, J., Kutová, E.: Methodology Guideline. Proposal of Indicators for Environmental Reporting and Annual Reports of EMAS (in Czech), Ministry of Environment of the Czech Republic, Praha (2010)

12. Hřebíček, J., Soukopová, J., Štencl, M., Trenz, O.: Corporate key performance indicators for environmental management and reporting. Acta Universitatis Agriculturae et Silviculturae Mendelianae Brunensis 59(2), 99-108 (2011) 